\title{
ОСОБЕННОСТИ И ФУНКЦИОНИРОВАНИЕ УСТАРЕВШЕЙ ЛЕКСИКИ В СКАЗКАХ А. С. ПУШКИНА
}

Аннюк Е. А. Особенности и функционирование устаревшей лексики в сказках А. С. Пушкина.

В статье исследуются особенности архаизмов как пласта устаревшей лексики русского языка на материале сказок А. С. Пушкина, определяется их соответствие лексическим и семантическим типам архаизмов и функционирование в языке художественной литературы, анализируются устаревшие грамматические формы.

Ключевые слова: архаизмы, старославянизмы, древнерусизмы, лексическое значение, средство стилизации.

Аннюк О. А. Особливості та функціонування застарілої лексики в казках О. С. Пушкіна.

У статті досліджуються особливості архаїзмів як пласта застарілої лексики російської мови на матеріалі казок О.С. Пушкіна, визначається їх відповідність лексичним та семантичним типам архаїзмів і функціонування в мові художньої літератури, аналізуються застарілі граматичні форми.

Ключові слова: архаїзми, старослов'янізми, давньорусизми, лексичне значення, засіб стилізації.

Annyuk E. A. Peculiarities and functioning of obsolete lexis in Pushkin's tales.

The publication studies the main characteristics of the archaisms as the type of the obsolete lexis based on the material from Pushkin's tales, where this material is determined in agreement with the lexical and semantic type of archaisms and with stylistic in the vocabulary of literature. We also analyze archaistic grammatical forms.

Key words: archaisms, Old Slavonic and Old Russian lexis, lexical meaning, means of stylization.

Изучение лингвистических особенностей художественного является одной из актуальных проблем современного языкознания. Слово играет самую важную роль в системе языка. О неисчерпаемых возможностях слова метко писал С. Маршак: «Человек нашел слова для всего, что обнаружено им во вселенной. Но этого мало. Он назвал всякое действие и состояние. Он определил словами свойства и качества всего, что его окружает. Словарь отражает все изменения, происходящие в мире. Он запечатлел опыт и мудрость веков и, не отставая, сопутствует жизни, развитию техники, науки, искусства, Он 
может назвать любую вещь и располагает средствами для выражения самых отвлеченных и обобщающих идей и понятий» [7, с. 254].

Как отмечают исследователи (В. В. Виноградов, А. Н. Гвоздев, И. Б. Голуб, В. Я. Дерягин, В. В. Лопатин, Д. Э. Розенталь, Д. Н. Шмелев и др.), язык никогда не стоит на месте: если это живой язык, используемый каким-либо народом в качестве средства общения, он постоянно развивается. Изменяется его словарный состав, фонетика, грамматика. «Одни явления - слова, грамматические формы, звуки устаревают в нем, отходят в прошлое, другие - только нарождаются, возникают, чтобы получить широкое распространение. Поэтому прошлое крепко связано в языке с настоящим» [5, с. 78].

В каждый период развития языка в нем есть лексика, постоянно используемая в речи, принадлежащая к активному словарному запасу, и лексика пассивного словарного запаса, которую составляют слова, вышедшие из повседневного употребления и получившие архаическую окраску. Безусловно, принадлежность слова к активному или пассивному лексическому запасу оказывает существенное влияние на его стилистическую окраску, а следовательно, и на использование в речи. Принципиально различаются в стилистическом отношении устаревшие и новые слова.

Изучению устаревшей лексики, ее месту и роли в современном русском литературном языке посвящено большое количество исследований, однако вопрос этот все так же остается актуальным в языкознании. И прежде всего потому, что, как представляется, недостает именно конкретно-исторических работ, содержащих большой фактический материал, прослеживающий историю, судьбу этого пласта лексики, анализирующих особенности функционирования устаревшей лексики, в том числе старославянизмов и древнерусизмов в языке художественных произведений.

Интерес к истории языка, к процессам становления его фонетической и грамматической систем, о стилистических функциях словарного богатства определил выбор темы и актуальность данной статьи - определить и проанализировать особенности функционирования старославянизмов как лексики пассивного словаря русского языка на материале сказок А. С. Пушкина.

В современном русском языке достаточно много старославянских элементов и они прочно освоены носителями языка. Наличие в нашем речевом обиходе слов время, храбрый, жизнь, () Е. А. Аннюк, 2012. 
жажда, облака, требовать привычно настолько, что кажется словарным багажом русского языка. Однако это лексика, заимствованная из старославянского языка. И. Б. Голуб отмечал: «Лексика, переставшая активно использоваться в речи, забывается не сразу. Какое-то время устаревшие слова понятны говорящим, знакомы им по художественной литературе, хотя при общении людей в них не возникает потребности» [2, с. 156]. Приведенные выше примеры свидетельствуют о том, что такие заимствования прочно закрепились в лексике русского языка, так как оказались более востребованными в речи, чем однокоренные исконно русские: веремя, хоробрый, жажа (диал.), обвлака, теребить. Отдельные устаревшие слова возвращались в состав лексики активного словарного запаса после их «исчезновения» из речи на некоторое время (слова солдат, прапорщик, тунеядец вновь активно используются в речи).

Особая эмоционально-экспрессивная окраска устаревших слов накладывает отпечаток на их семантику. Поэтому устаревшие слова поставлены в особые стилистические рамки, что требует к ним особого внимания. Наряду с ассимилировавшими на русской почве и стилистически слившимися с нейтральной русской лексикой славянизмами есть в русском языке и такие старославянские слова, которые, безусловно, воспринимаются как стилистически окрашенные, сохраняющие торжественную, риторическую окраску. Писатели часто обращаются к ресурсам устаревшей лексики как к выразительному средству художественной речи, что служит богатым материалом для лингвистических исследований. Н. М. Шанский утверждал: «Как язык является первоэлементом литературы, так и лингвистический анализ текста является фундаментом его литературоведческого и стилистического изучения» [9, с. 53].

А. С. Пушкина по праву называют великим новатором и реформатором в области языка. Поэт в совершенстве знал родной язык, несмотря на условности современной ему эпохи и дворянского общества изъясняться по-французски. Стихи и проза Пушкина в большой степени способствовали развитию и расцвету русского литературного языка.

Язык Пушкина и по сей день в центре внимания ученыхфилологов. Словарь А.С.Пушкина, составленный по его произведениям, включает 21 тысячу слов, что свидетельствует об отношении поэта к русскому слову, русской речи в целом, о значении родного языка в его жизни и творчестве. Каждое произведение 
Пушкина - свидетельство богатства и красоты русской речи, ее многовековых накоплений и приобретений, выразительности, чистоты, духовности. В языке Пушкина вся предшествующая русская речевая культура не только достигла своего высшего расцвета, но и получила качественное преобразование. Поэт стремился создать «язык общепонятный», что было возможно при объединении всех социальноречевых стилей русского языка: и древнеславянизмов и «славянорусизмов», и книжных и разговорных элементов литературного языка предшествующей поры, и просторечия широких масс, и живой устной речи простого народа [1, с. 73]. Разработав новые приемы использования языка в художественной литературе, Пушкин выступает преобразователем русской литературной речи. Синтез разнородных элементов, который осуществился в его творчестве, определил особенности и отразил процесс демократизации литературного языка. Поэтому вполне понятен пристальный интерес критики к языковым особенностям пушкинских произведений.

В творчестве А.С. Пушкина сказки занимают особое место. Сказки, услышанные им от своей няни, под пером поэта обрели свою стихотворную форму и воплощение в ней выразительных средств родного языка. Особенно ценил поэт в русской сказке черты народности: «живописный способ выражаться», «русское раздолье ума». Язык сказок, по мнению поэта, разнообразнее книжного языка и ярче его по своим выразительным средствам и краскам [1, с. 74]. В литературный язык своих произведений А. С. Пушкин отбирал только то, что, по его мнению, составляло коренные основы национального языка. Старославянизмы наряду с древнерусскими словами как значительный пласт устаревшей лексики были неотъемлемой частью творческого словаря Пушкина, являя собой стилистически необходимое и оправданное средство языка, придавая произведениям индивидуальные качества и колорит.

Рассмотрим примеры использования старославянизмов в сказках А. С. Пушкина. Материалом для исследования послужили следующие сказки поэта: «Сказка о царе Салтане, о сыне его славном и могучем богатыре Гвидоне Салтановиче и о прекрасной царевне Лебеди», «Сказка о рыбаке и рыбке», «Сказка о попе и о работнике его Балде», «Сказка о мертвой царевне и о семи богатырях», «Сказка о золотом петушке».

Для удобства анализа старославянизмов как пласта устаревшей лексики мы будем придерживаться классификации типов архаизмов (к ним () Е. А. Аннюк, 2012. - 86 - 
в лингвистике относят старославянизмы), предложенной А. В. Калининым. Ученый выделяет архаизмы лексические и семантические (смысловые). В лексические он включает: а) архаизмы лексико-фонетические; б) лексикословообразовательные; в) собственно-лексические.

В текстах таких сказок, как «Сказка о царе Салтане...», «Сказка о мертвой царевне...». «Сказка о золотом петушке», «Сказка о рыбаке и рыбке» встречаются старославянские по происхождению слова, что подтверждается наличием у них фонетических признаков старославянизмов. Это слова с неполногласными сочетаниями -pa-, -ла- в корнях: бранный, брег, град, глава, златоглавыц̆, пред, прекрасный, страж, нрав, чредой.

Наличие показательных признаков позволяет отнести группы таких слов к лексико-фонетическому типу архаизмов:

«Мать и сын идут ко граду.

Лишь ступили за ограду,

Оглушительный трезвон

Поднялся со всех сторон...»;

«И ияаревича венчают

Княжеей шапкой, и главой

Возглашают над собой»;

«Город новый златоглавый...»;

«Здравствуй, князь ты мой прекрасный!»;

«И желанная страна

Вот уж издали видна»;

«И останутся на бреге

Тридиать три богатыря,

В чешуе златой горя...» («Сказка о царе Салтане...»);

«Еще пуще старуха бранится...»;

«Вкруг нее стоит грозная стражна...»

(«Сказка о рыбаке и рыбке»);

Большинство неполногласных корней старославянского происхождения существует в современном русском языке параллельно с полногласными русскими морфемами. Так, в «Сказке о мертвой царевне и о семи богатырях» встречаются следующие примеры с неполногласием:

«Белолица, черноброва,

Нраву кроткого такого»;

«Нами ты была любима

И для милого хранима...». 
Отмеченные старославянские слова являются однокоренными со словами норов, норовистый, хоронить, приобретшими в современном русском языке несколько иные значения. В целом, приведенные примеры подтверждают, что фонетический облик некоторых устаревших слов имел характерные для заимствований особенности. Такие старославянизмы отличаются от современных вариантов тех же слов обычно одним звуком, напр. страж - сторож, пред - перед, глава - голова, чреда - очередь. Вместе с тем прочно закрепились в русском литературном языке и слова с неполногласием: страна, благодарность, разглашать. Примеры таких старославянизмов обнаруживаются и в сказках А. С. Пушкина:

\section{«И желанная страна}

Вот уж издали видна» («Сказка о царе Салтане...»);

«Перед ним молва бежала,

Быль и небыль разглашала» («Сказка о золотом петушке»).

Как видим, старославянские по происхождению слова, которые встречаются в текстах сказок Пушкина, однозначно отнести к устаревшей лексике нельзя, так как русский литературный язык богат и активно функционирующими в речи старославянизмами. Использование поэтом старославянских заимствований в сказках, очевидно, продиктовано тем, что во времена Пушкина старославянизмы были достоянием поэтической речи и употреблялись в качестве слов высокой лексики, не воспринимаясь как архаизмы. Кроме того, неполногласные формы как более короткие в звучании лучше укладывались в размер стиха.

К следующей группе лексических архаизмов лингвистическая наука относит архаизмы лексико-словообразовательные, примеры которых также встречаются в текстах пушкинских сказок. Особенностью этой группы архаизмов является наличие отдельных устаревших словообразовательных элементов, чаще всего суффиксов. В сказках А. С. Пушкина находим следующие примеры:

«Беса старого взяла тут унылость»;

«Попадья говорит: «Знаю средство,

Как удалить от нас такое бедство...»;

«Окажи свое усердие и проворье»

(«Сказка о попе и работнике его Балде»); «Братья в горести душевной»

(«Сказка о мертвой царевне...»).

Присутствие в морфологической структуре выделенных слов устаревших суффиксов -осmb-, -есть-, -ств-, -j- является свидетельством () Е. А. Аннюк, 2012. 
архаичности этих имен существительных. Автор же намеренно использует подобную лексику для стилизации старинной речи, для создания речевого колорита. Однако в данном случае стилизация имеет место не только при передаче речи персонажей, но и в языке самого автора.

Чтобы подчеркнуть особый колорит русской древности, обратить внимание читателя на поэтичность лексики сказок, которые содержат, безусловно, фольклорные элементы, Пушкин активно использует собственно-лексические архаизмы, пришедшие из старославянского и древнерусского языков и устаревшие совсем: инда (так что), персты (пальцы), очи (глаза), яства (еда, угощение), кабы (если бы), витязи (богатыри), бают (говорят), ныне (сегодня, тотчас), латы (защитная броня вочна), ратный (военный), чета (пара), осьмой (восьмой), сей (этот). Понимание значений перечисленных слов данной группы было бы весьма затруднительно для современного читателя сказок Пушкина, так как такое их звучание не характерно для нашей эпохи по причине устарелости. Но значения не утратились окончательно, а приобрели новый звуковой облик, тем самым образуя синонимы устаревших слов, значения которых не исчезли из живого языка. Именно наличие в современном языке соответствующих синонимов позволяет понять значение архаизмов в следующих строках:

«Но под старость захотел

Отдохнуть от ратных дел»;

«Инда плакал ичарь Дадон,

Инда забывал и сон»;

«Всяким яством угощала»

(«Сказка о золотом петушке»).

«Ум у бабы догадлив,

На всякие хитрости повадлив»

(«Сказка о попе и работнике его...); «Она бьет их, за чупрун таскает...»

(«Сказка о рыбаке и рыбке»).

Анализ языка сказок Пушкина показывает, что при использовании устаревшей лексики для стилизации текста, а также как средства выразительности поэтической речи автор в большей степени обращается к ресурсам старославянской лексики, поскольку преимущественно славянизмы употреблялись в поэзии XVIII-XIX веков. Однако в текстах сказок встречаются и исконно русские устаревшие слова, например: 
невежа, шелом, череда, ровная (в значении «подобная, такая же»). Так, в «Сказке о рыбаке и рыбке» есть строки:

\section{«Поделом тебе, старый невежа!}

Впредь тебе, невежа, наука...»,

где слово «невежа» имеет фонетический облик, характерный для языков восточнославянской группы и употребляется со значением - «ррубый, невоспитанный человек». Этимологически «невежа» восходит к общеславянскому «ведети» - «знать, быть осведомленным». В старославянском языке с таким же лексическим значением закрепилось как «невежда» с сочетанием жд в корне, которое в южнославянских языках чередуется с $\partial$. Для исконно русских слов такое чередование не характерно.

$\mathrm{B}$ «Сказке о золотом петушке» автор предпочитает славянизму «илем», вошедшему в активную лексику русского языка, исконно русское слово «шелом» с характерным для последнего полногласием «ело» в корне:

\section{«Перед ним его два сына}

Без шеломов и без лат».

С восточнославянским полногласием «ере» находим слово «черед $a »$ в «Сказке о попе и работнике его Балде»:

«Нет, - говорит Балда, Теперь моя череда...».

$\mathrm{B}$ «Сказке о мертвой царевне...» одна из героинь заявляет: «Обойди все изарство наше, Хоть весь мир, мне ровной нет».

Выделенное слово - русское по происхождению, о чем свидетельствует начальное сочетание «ро», характерное для языков восточнославянской группы. В контексте сказки значение слова иное, нежели мы привыкли его воспринимать, так как «ровная» здесь обозначает «такая же, подобная», а не «гладкая, без шероховатостей».

Таким образом, исконно русская устаревшая лексика, хоть и в меньшей мере, также встречается в поэтических сказках А. С. Пушкина, обогащая и наполняя выразительностью жанровое своеобразие произведений.

Кроме лексических архаизмов в пушкинских сказках встречаются примеры и семантических (смысловых) типов устаревшей лексики многозначных слов, у которых устарело одно или несколько значений. В «Сказке о царе Салтане» таковым является слово «гости», которое автор 
использует и в значении «купцы, иноземные торговцы» (1) и в значении «гость» - «человек, пришедший навестить кого-либо» (2):

«Пристают к заставе гости; (1)

Князь Гвидон зовет их в гости...» (2)

Примером семантического архаизма является и слово «красный», встречающееся в «Сказке о царе Салтане...», «Сказке о мертвой царевне...»: «Здравствуй, красная девица....», «Не видал я девыл красной...».

Древнее слово «красный» общеславянского происхождения и, в отличие от современного значения одного из основных цветов спектра, обозначало оно «красивый, прекрасный внешне», будучи образованным от слова «краса». В древнерусском языке слово «красный» употреблялось для определения всего прекрасного, хорошего, радостного не только в отношении людей, но и для всего красивого, что окружало людей. В этом значении слово «красный» было широко распространено в народной речи, устном народном творчестве, из которых А. С. Пушкин черпал вдохновение и мотивы для своей поэзии. Его знание устаревших значений - свидетельство того, насколько великий мастер слова владел ресурсами родного языка.

Кроме лексико-семантических особенностей устаревших слов, встречаемых в пушкинских сказках, наше внимание привлекают и их особые грамматические формы как предмет исторической грамматики.

Образцы грамматических форм некоторых частей речи, использованных Пушкиным в сказках, были характерны для древнерусской морфологической системы, особенности которой изучались лингвистами по памятникам славянской письменности. Очевидно, в просторечии, в фольклоре такие реликты еще присутствовали и были знакомы поэту, который «оживил» их в литературном языке.

К примеру, в «Сказке о рыбаке и рыбке» автор многократно использует как стилистический прием форму утраченного в древнерусском языке периода XI в. звательного падежа имени существительного: «Чего тебе надобно, старче?»

$\mathrm{B}$ «Сказке о царе Салтане...» Пушкин использует склоняемую в древнерусском языке форму именного (нечленного) прилагательного: «Царь Салтан, с женой простяся

На добра коня садяся...».

Однако, затруднено определение формы - именной или местоименной - у прилагательных «тих, как день», «бель руки», так как в форме именительного падежа (в указанных примерах) 
наблюдается их соответствие современным кратким прилагательным, которые не имеют форм косвенных падежей, в отличие от древнерусских именных прилагательных. Все же употребление таких форм прилагательного в качестве эпитетов служит как образной характеристикой персонажей, так и большей выразительности и красочности языка сказок.

Интересным фактом, на наш взгляд, является использование Пушкиным одного и того же существительного с разными показателями родовой принадлежности. Например, в «Сказке о царе Салтане...» существительное «лебедь» женского рода: «Лебедь белая nльввет», в названии - форма предложного падежа существительных женского рода «...о прекрасной цзаревне Лебеди»; в «Сказке о золотом петушке» - мужского рода: «Весь как лебедь поседельй». Поэту, несомненно, было известно о принадлежности этого слова к существительным женского рода в древнерусском языке, хотя в эпоху его творчества родовая принадлежность «лебеди» изменилась. Обращение к подобным историческим явлениям в языке позволило более ярко представить образы сказочных персонажей.

Примером использования Пушкиным устаревших грамматических форм является употребление существительного в форме именительного падежа вместо винительного объекта действия. Такие формы существовали в русском языке древнейшей поры как показатель отсутствующей грамматической категории одушевленности, о чем свидетельствуют памятники древнерусской письменности (Лаврентьевская, Радзивиловская летописи и др.). Подобная форма именительного падежа существительного вместо винительного встречается в «Сказке о золотом петушке»:

«Медлить нечего: «Скорее! Люди, на конь! эй, живее!»

Вполне вероятно, что в просторечии русского языка XIX века такие формы еще встречались и были знакомы поэту, который использовал их как средство стилизации старинной речи и передачи колорита эпохи древности, пусть и сказочной.

Проведенный нами анализ языка сказок А. С. Пушкина позволяет отметить, что, наряду с лексикой активного словарного запаса русского языка поэт использует устаревшую лексику - старославянизмы и древнерусизмы - как средство стилизации старинной речи (речь персонажей), речи авторской, передачи колорита эпохи древности, 
придания выразительности и образности языку сказок как вида устного народного творчества, что определяет художественную ценность фольклора. Мастерское обращение с родным словом позволило поэту оживить язык своих произведений, придав им эмоциональноэкспрессивную окрашенность. Исследуя лексику пушкинских сказок, читатель не только может оценить богатство русского языка, но и приобщиться к культурно-историческому наследию славянского народа. Кроме этого, лексический материал сказок А. С. Пушкина может быть использован для решения дидактических задач при изучении исторической грамматики в вузах и лексикологии в высших и средних учебных заведений.

\section{Литература}

1. Виноградов В. В. Значение А. С. Пушкина в истории русского литературного языка и в истории стилей русской художественной литературы / В. В. Виноградов // Русская речь. - 1990. - № 3. - С. 69-78.

2. Голуб И. Б. Стилистика современного русского языка / Ирина Борисовна Голуб. - М. : Высшая школа, 1986. - 336 с.

3. Калинин А. В. Лексика русского языка / Александр Васильевич Калинин. Издательство Московского университета, 1978. - 232 с.

4. Кузнецов П. С. Очерки морфологии русского языка / Петр Савич Кузнецов. М. : Издательство Академии наук СССР, 1959. - 275 с.

5. Лопатин В. В. Зачем языковеды изучают историю языка? / В. В. Лопатин // Русская речь. - 1967. - № 5. - С. 77-85.

6. Лопушанская С. П. Страницы истории русского языка / С. П. Лопушанская, О. А. Горбань, Е. М. Шептухина. - М. : Просвещение, 2007. - 191 с.

7. Маршак С. Я. Собрание сочинений: в 8-ми томах / Самуил Яковлевич Маршак. М. : Художественная литература. - Т.7. - 1971. - 456 с.

8. Устинов И. В. Очерки по русскому языку. Часть 1. Историческая грамматика русского языка / Иван Васильевич Устинов. - М. : 1959. - 382 с.

9. Шанский Н. М. Лингвистический анализ и лингвистическое комментирование художественного текста / Николай Максимович Шанский // Русский язык в школе. 1983. - № 3. - C. 53-54.

\section{Использованные источники:}

1. Пушкин А. С. Стихи и сказки / Александр Сергеевич Пушкин. - М. : Издательство «Детская литература», 1974. - 160 с.

Стаття надійшла до редакції 20.09.2012 р. 